\title{
Heart transplantation: review
}

\author{
Transplante cardíaco: revisão
}

\author{
Sandrigo Mangini ${ }^{1}$, Bárbara Rubim Alves ${ }^{1}$, Odílson Marcos Silvestre ${ }^{2}$, Philippe Vieira Pires ${ }^{1}$, \\ Lucas José Tachotti Pires ${ }^{1}$, Milena Novaes Cardoso Curiati ${ }^{1}$, Fernando Bacal ${ }^{1}$
}

\begin{abstract}
Heart transplantation is currently the definitive gold standard surgical approach in the treatment of refractory heart failure. However, the shortage of donors limits the achievement of a greater number of heart transplants, in which the use of mechanical circulatory support devices is increasing. With well-established indications and contraindications, as well as diagnosis and treatment of rejection through defined protocols of immunosuppression, the outcomes of heart transplantation are very favorable. Among early complications that can impact survival are primary graft failure, right ventricular dysfunction, rejection, and infections, whereas late complications include cardiac allograft vasculopathy and neoplasms. Despite the difficulties for heart transplantation, in particular, the shortage of donors and high mortality while on the waiting list, in Brazil, there is a great potential for both increasing effective donors and using circulatory assist devices, which can positively impact the number and outcomes of heart transplants.
\end{abstract}

Keywords: Heart transplantation; Heart transplantation/adverse effects; Infections; Graft rejection

\section{RESUMO}

0 transplante cardíaco é atualmente a abordagem cirúrgica definitiva padrão-ouro no tratamento da insuficiência cardíaca refratária. No entanto, a escassez de doadores limita a realização de um número maior de transplantes cardíacos, situação em que vem aumentando a utilização de dispositivos de assistência circulatória mecânica. Com indicações e contraindicações bem estabelecidas, além de diagnóstico e tratamento de rejeição, por meio de protocolos definidos de imunossupressão, os resultados do transplante cardíaco são muito favoráveis. Dentre as complicações precoces que podem impactar a sobrevida, destacamos a disfunção primária do enxerto, a disfunção do ventrículo direito, rejeição e infecções; já as complicações tardias incluem a doença vascular do enxerto e as neoplasias. Apesar das dificuldades para realização do transplante cardíaco, em especial pela escassez de doadores e pela elevada mortalidade em fila de espera, no Brasil, existe um grande potencial, tanto no aumento de doadores efetivos, quanto na utilização de dispositivos de assistência circulatória, o que pode vir a impactar positivamente no número e nos resultados do transplante cardíaco.

Descritores: Transplante de coração; Transplante de coração/efeitos adversos; Infecções; Rejeição de enxerto

\section{INTRODUCTION}

The first heart transplant (HT) was performed in 1967 by Christian Barnard, in South Africa, and six months later, Euryclides Zerbini did the first HT in Brazil. Despite initial euphoria, the results were not satisfactory, with a high mortality rate. At the end of the 1970's, with the appearance of cyclosporine, which allowed a better control of rejection, there was great development in performance of transplants in general, including HT.

HT is currently the definitive gold-standard surgical approach in the treatment of refractory heart failure (HF), a situation in which the patient presents with great functional limitation and high mortality rate.(1) Nevertheless, the scarcity of donors expressively limits the performance of a greater number of HT, a situation that has increasingly expanded the indication and use of mechanical circulatory assistance devices. ${ }^{(2)}$

With an expressive increase in the number of HT until the mid-1990s, due to improvement in the clinical treatment of $\mathrm{HF}$ and the inherent limitation of donors, the number of HT in the world has remained stable approximately 4,000 a 5,000 per year. ${ }^{(2)}$ In Brazil, there

\footnotetext{
Hospital Israelita Albert Einstein, São Paulo, SP, Brazil.

${ }^{2}$ Instituto do Coração, Hospital das Clínicas, Faculdade de Medicina, Universidade de São Paulo, São Paulo, SP, Brazil.

Corresponding author: Sandrigo Mangini - Avenida Albert Einstein, 627/701, building A1, 4th floor, room 420 - Morumbi - Zip code: $05652-900$ - São Paulo, SP, Brazil - Phone: (55 11) 2151-5420 E-mail: sanmangini@ig.com.br
}

Received on: May 5, 2014 - Accepted on: Feb 8, 2015

DOI: 10.1590/\$1679-45082015RW3154 
is a perspective of increase in the number of HT since only $11 \%$ of the donors are utilized. In 2014, 311 HT were performed, which is a historic record, reaching 1.6 transplants per million in the population $(\mathrm{pmp}) .^{(3)}$

\section{INDICATIONS AND CONTRAINDICATIONS}

HT is a treatment that improves quality of life and survival of patients with refractory HF (stage D). Thus, patients that maintain functional classes III and IV, recurrent hospitalizations, and present with poor prognostic markers - despite therapeutic optimization (with medications and surgery) - should be considered for HT. In the evaluation, both subjective (functional class) and objective (physical examination and ancillary tests) data should be compiled to improve the accuracy of the indication. In this way, besides the clinical evaluation, it is appropriate to perform functional tests, such as cardiopulmonary and the 6-minute walk tests. Two parameters of the cardiopulmonary test are very useful, since they have a strong correlation with the prognosis of HF: oxygen consumption $\left(\mathrm{VO}_{2}\right)$ and the ventilation equivalent for carbon dioxide $\left(\mathrm{VE} / \mathrm{VCO}_{2}\right){ }^{(4)}$ Just as with other parameters demonstrated on chart 1 , these show the identification of candidates for heart transplantation. ${ }^{(1)}$

Chart 1. Indications and contraindications for heart transplant

\begin{tabular}{|ll|}
\hline Indications & \multicolumn{1}{c|}{ Contraindications } \\
\hline Refractory HF while using inotropics or VAD & Pulmonary hypertension (PVR $>5$ Wood units) \\
Persisting functional classes III or IV & Severe cerebrovascular diseases \\
$\mathrm{VO}_{2} \leq 12 \mathrm{~mL} / \mathrm{kg} / \mathrm{min}$ (use of a betablocker) & Severe peripheral vascular diseases \\
$\mathrm{VO}_{2} \leq 14 \mathrm{~mL} / \mathrm{kg} / \mathrm{min}$ (without beta blocker) & Severe liver failure \\
Ischemic disease with refractory angina & Severe pulmonary disease \\
and with no possibility of revascularization & \\
Persistent and refractory ventricular & ABO incompatibility in prospective \\
arrhythmia & crossmatching between donor and recipient \\
VENCO $>35$ or 6-minute walk test $<300 \mathrm{~m}$ & Severe psychiatric disease, chemical \\
& dependence, and poor compliance to \\
& treatment \\
\hline
\end{tabular}

Source: modified Bacal F et al.

$\mathrm{HF}$ : heart failure; $\mathrm{VAD}$ : ventricular assistance device; $\mathrm{VO}_{2}$ : oxygen consumption; $\mathrm{VENCO}_{2}$ : ventilatory equivalent for carbon dioxide; PVR: pulmonary vascular resistance.

The presence of comorbidities that limit survival or hinder surgical treatment and posteriorly, clinical treatment of the transplant recipient should be identified and evaluated for the indication and contraindication of a HT. Fixed pulmonary hypertension (especially with pulmonary vascular resistance $>5$ Wood units) is a limiting factor, since it is associated with early postoperative right ventricle (RV) failure. ${ }^{(5)}$ The main conditions that contraindicate the transplant are shown on chart 1. It is important to remember that certain conditions, such as untreated infections and neoplasms, can be transient limitations for a transplant, but may potentially revert, allowing eligibility for the treatment. In patients with diabetes mellitus, the presence of target organ lesions is the factor that determines contraindication for treatment. ${ }^{(6)}$ Not less important, pretransplant immunological evaluation includes the determination of the panel of reactive antibodies against HLA (PRA), which can make the transplant unfeasible, if there is positivity against specific antigens of the donor. ${ }^{(7)}$

\section{Early complications \\ Primary graft failure}

Primary graft failure is the first cause of early mortality after HT, corresponding to $36 \%$ of deaths in the first 30 days. $^{(2)}$ A recent consensus of the International Society for Heart and Lung Transplantation (ISHLT) defined primary failure of the graft as affecting the left and/or right ventricle with echocardiographic and hemodynamic alterations, need for inotropic/vasopressor support, and commonly, the use of circulatory assistance devices. ${ }^{(8)}$ Its prevalence varies between 1.4 and $30.7 \%$, due to heterogeneity of the populations studied and of the diagnostic criteria used in its definition. ${ }^{(8)}$ The main clinical manifestation is hemodynamic instability with cardiogenic shock, a result of a multifactorial process with contributions from elements of the donor, recipient, and the surgical procedure. ${ }^{(9)}$ Its pathophysiology is not well-defined, but it is known that a lesion by ischemiareperfusion, metabolic alterations after the donor's brain death, and care of the organ prior to the transplant, are factors that contribute towards its development. ${ }^{(10)}$ Treatment is based on intensive hemodynamic support with the use of vasoactive and inotropic drugs, and in more severe cases, of mechanical circulatory assistance devices, with limited retransplant results within this context. $^{(11)}$

\section{Right ventricle dysfunction}

Right ventricle (RV) dysfunction secondary to pulmonary hypertension is one of the situations of greatest concern after HT, and it accounts for up to $50 \%$ of heart complications and almost $20 \%$ of deaths in the early postoperative period. ${ }^{(12)}$ Recipients with pulmonary vascular resistance of more than 4 Wood units, systolic pressure in the pulmonary artery $>60 \mathrm{mmHg}$ or 
transpulmonary gradient (difference between mean pulmonary arterial pressure and pulmonary capillary wedge pressure) $>15 \mathrm{mmHg}$, present with a high risk of RV failure, a condition aggravated by the development of hypoxemia and acidosis. ${ }^{(1)}$

Preoperative preparation of these patients should include evaluation of the presence and responsiveness of pulmonary hypertension to vasodilators, and optimization of HF treatment with the use of inotropic agents and vasodilators, and, if necessary, circulatory assistance devices. During the intraoperative period, it is fundamental to exclude mechanical causes, such as torsion or angulation in the pulmonary artery anastomosis, and pay attention to the output of extracorporeal circulation, to the possibility of a reaction to protamine with pulmonary vasoconstriction and gas embolism.

The rationale of treatment is optimization of RV preload, aiming at normovolemia, reduction of pulmonary vascular resistance with the use of vasodilators (nitroprusside, nitric oxide, prostacyclin, and sildenafil) and increased myocardial contractility. The inotropic agents that may be used include dobutamine, adrenaline, milrinone, and isoproterenol. Mechanical ventilation should be adjusted with the purpose of avoiding hypoxia and elevated ventilatory pressures. If there is no adequate response, the use of circulatory assistance devices should be considered..$^{(1,11)}$

\section{Infections}

Infectious complications, along with primary graft failure, are among the principal causes of mortality during the first three years after transplant, corresponding to $12 \%$ of deaths in the first 30 days and $29 \%$ between one month and one year (excluding infections by cytomegalovirus - CMV). ${ }^{(2)}$ Among the primary etiologies, the infections due to opportunistic agents, resulting from the immunosuppression used, stand out.

During the first month after transplant, hospital infections prevail, most of them of bacterial etiology and dependent on the hospital flora of each organization. There are also a few less severe opportunistic infections, such as reactivations of herpes simplex and mucocutaneous candidiasis. Surgical site infections also appear during this period and, despite being rare (less than 5\%), they present with high mortality (up to $14 \%$ in cases of mediastinitis). ${ }^{(1)}$ As of the second month, the main opportunistic infections prevail, especially CMV, toxoplasmosis, Chagas' disease reactivation, aspergillosis, pneumonia by Pneumocystis jirovecii, among others. From the sixth month on, with tapering of immunosuppression, extra-hospital infections similar to those that occur in immunocompetent patients become more frequent, but with a tendency to develop more severe cases. ${ }^{(1)}$

\section{REJECTION AND IMMUNOSUPPRESSION}

According to the latest ISHLT register, the incidence of graft rejection has been progressively falling over the last years. In 2010, it reached its nadir at approximately $25 \%$, thanks to the development of immunosuppression drugs and strategies. Additionally, it has long quit being the primary cause of mortality, and is responsible for less than $10 \%$ of post-HT deaths. ${ }^{(2)}$

\section{Rejection}

An endomyocardial biopsy is the gold standard for the correct and early diagnosis of rejection. ${ }^{(1)}$ In the initial phases of the transplant, it is frequently performed, and later, by adjusting immunosuppressors and the pathological profile, this biopsy is less often required. The clinical symptoms of rejection are varied, and in most cases, the patients are asymptomatic. No sign or symptom is pathognomonic of rejection; however, when present, may include unspecific constitutional symptoms (malaise, myalgia, and fever), myocardial inflammation (tachycardia, atrial or ventricular arrhythmias, pericardial effusion) and, in a more evident form, a clinical condition suggestive of HF (exertional dyspnea, asthenia, syncope, orthopnea, paroxysmal nocturnal dyspnea and, upon physical examination, jugular stasis, third heart sound, hypotension, pulmonary and/or systemic congestion).

Classically, three types of rejection have been documented: hyperacute, cellular, and humoral (or mediated by antibodies). ${ }^{(1)}$

Very severe and related to the presence of previously formed antibodies against the donor (ABO system, HLA, or endothelium), hyperacute humoral rejection is infrequent, thanks to the performance of ABOcompatible transplantation and to pretransplant PRA.

Acute cellular rejection is the most frequent type and is characterized by the presence of inflammatory cells in the myocardium. It is classified into four grades, as demonstrated on chart 2. ${ }^{(13)}$ Both the $2 \mathrm{R}$ and $3 \mathrm{R}$ grades require additional immunosuppressive treatment, which includes pulse therapy with corticosteroids, and in the presence of hemodynamic instability characterized by symptoms of $\mathrm{HF}$ and ventricular dysfunction seen on the echocardiogram, the association of antilymphocyte antibodies (thymoglobulin).

Acute humoral rejection or mediated by antibodies, despite many yet unanswered questions, ${ }^{(14)}$ has been considered a clinical-pathological entity that tends to 
Chart 2. Classification of acute cellular rejection

\begin{tabular}{|ll|}
\hline Grade & \multicolumn{1}{c|}{ Description } \\
\hline $\mathrm{OR}$ & Absence of inflammatory infiltration in the myocardium \\
grade) & $\begin{array}{l}\text { Perivascular or interstitial lymphohistiocytic inflammatory } \\
\text { infiltrate, with no aggression to myocytes or only one } \\
\text { aggression focus }\end{array}$ \\
$\begin{array}{l}\text { 2R (moderate rejection, } \\
\text { intermediate grade) }\end{array}$ & $\begin{array}{l}\text { Presence of two or more foci of aggression to the myocytes } \\
\text { (multifocal) }\end{array}$ \\
$\begin{array}{l}\text { 3R (serious rejection, } \\
\text { high grade) }\end{array}$ & $\begin{array}{l}\text { Diffuse pattern inflammation and multiple areas of cellular } \\
\text { aggression, often with polymorphic character of inflammatory } \\
\text { infiltrate, including neutrophils and eosinophils, hemorrhage, } \\
\text { vasculitis, and necrosis of myocytes }\end{array}$ \\
\hline
\end{tabular}

Source: Modified from: Stewart S et al.113

occur in allosensitized individuals (exposed to transfusion, gestations, transplants, circulatory assistance devices). It is characterized by the presence of antibodies (mainly anti-HLA) against the vascular endothelium of the graft, and within this context, is associated with a worse clinical progress. ${ }^{(15,16)}$ Due to the recent standardization of its diagnosis, it is difficult to establish a true incidence of humoral rejection, but it is estimated at approximately 10 to $15 \%$ at the end of the first year. ${ }^{(17)}$ From the pathological viewpoint, the most recent classification includes histopathological $(\mathrm{H})$ and immunopathological (I) information, and is divided into four grades of antibody mediated rejection (pAMR, pathologic antibody mediated rejection), as per chart $3 .{ }^{(14)}$ In the presence of hemodynamic instability characterized by signs and symptoms of HF and ventricular dysfunction on echocardiography, related to humoral rejection, due to the high risk of death, treatment should be aggressive, including pulse therapy with corticosteroids, antilymphocyte antibodies, immunoglobulin, plasmapheresis, and drugs that block the production of antibodies by B lymphocytes (rituximab), antibodies (bortezomib) or the complement (eculizumab). ${ }^{(1)}$

Chart 3. Classification of antibody mediated rejection

\begin{tabular}{|ll|}
\hline pAMR 0 & $\begin{array}{l}\text { Negative for antibody mediated rejection (negative histopathological and } \\
\text { immunopathological studies) }\end{array}$ \\
pAMR 1(H+) & $\begin{array}{l}\text { Antibody-mediated rejection is only histopathological (absence of } \\
\text { immunopathological findings and presence of histopathological } \\
\\
\text { findings - activated mononuclear cells, endothelial edema, hemorrhage, } \\
\text { interstitial edema and/or necrosis of myocytes) }\end{array}$ \\
pAMR 1(I+) & $\begin{array}{l}\text { Antibody-mediated rejection is only immunopathological (absence of } \\
\text { histopathological findings and presence of immunopathological findings } \\
\text { pAMR 2 }\end{array}$ \\
& $\begin{array}{l}\text { Defined by the presence of histopathological and immunopathological } \\
\text { findings for antibody-mediated rejection }\end{array}$ \\
pAMR 3 & $\begin{array}{l}\text { Serious antibody mediated rejection characterized by the presence } \\
\text { of hemorrhage, capillary fragmentation, polymorphic inflammation, } \\
\text { interstitial edema, and immunopathological markers }\end{array}$ \\
\hline
\end{tabular}

pAMR: pathologic Antibody Mediated Rejection. Modified from: Berry GJ et al.(14)
Despite a worse prognosis well-established in patients with a diagnosis of humoral rejection, there is great doubt in literature as to its treatment in asymptomatic individuals with normal ventricular functions, due to the inherent risk of more intensive immunosuppressive strategies. ${ }^{(14)}$

\section{Immunosuppression}

According to the most recent registry of HT by ISHLT, ${ }^{(2)}$ the triple regimen -including corticosteroid, calcineurin inhibitor and an antiproliferative agent - continues to be routinely used at most services and to be confirmed by the guidelines..$^{(1,18)}$

\section{Corticosteroids}

These are used at high doses during the initial phases and in acute rejection episodes. Due to numerous side effects, primarily metabolic and cardiovascular, their removal has been recommended as of the sixth month post-HT, ${ }^{(19)}$ especially in patients with a favorable history of rejection.

\section{Calcineurin inhibitors}

Cyclosporine and tacrolimus are calcineurin inhibitors. Studies comparing the two drugs demonstrated similar survival results, ${ }^{(20,21)}$ including the incidence of rejection and cardiac allograft vasculopathy (CAV). In more recent studies, a smaller incidence of rejection has been demonstrated with tacrolimus in comparison with cyclosporine. ${ }^{(22,23)}$ In situations of persistent rejection (resistant to corticosteroids), it is advisable to exchange cyclosporine for tacrolimus. ${ }^{(24)}$ As per the ISHLT, tacrolimus is the most used calcineurin inhibitor. In Brazil, for HT, the Ministry of Health makes available only cyclosporine as a calcineurin inhibitor. Nevertheless, there is the perspective of tacrolimus soon also being made available for HT, especially in patients at high risk of rejection (young people, black ethnicity, and females).

\section{Antiproliferative agents}

This is the case of azathioprine and mycophenolate. Studies comparing azathioprine and mycophenolate in HT revealed superiority of mycophenolate, regarding rejection and survival, ${ }^{(25,26)}$ and a possible reduction of CAV and neoplasms, ${ }^{(27,28)}$ while gastrointestinal symptoms, infections by CMV, herpes simplex and herpes-zoster favor azathioprine. ${ }^{(29)}$ Based on these results, mycophenolate became the antiproliferative agent of choice in HT in association with calcineurin inhibitors and corticosteroids. Additionally, in situations 
of severe or persistent rejection of patients who already used azathioprine chronically, the change to mycophenolate has been recommended. In patients with Chagas' disease, two Brazilian studies on HT demonstrated a high incidence of reactivation of the Chagas' disease with mycophenolate, ${ }^{(30,31)}$ bringing up the discussion on the possibility of using azathioprine or lower doses of mycophenolate in this population.

\section{mTOR inhibitors}

These are sirolimus and everolimus. Some studies with both drugs demonstrated a reduction in incidence ${ }^{(32,33)}$ and a decrease in the progression of cardiac allograft vasculopathy (CAV), ${ }^{(34)}$ improvement/preservation of renal function in the regimes with removal/reduction of cyclosporine, and reduction of neoplasms and viral infections. ${ }^{(35,36)}$ On the other hand, in combined regimes with cyclosporine (at the habitual does), it is related to worsening of the renal function; ${ }^{(32)}$ if withdrawing cyclosporine (seeking improved renal function), it may increase the incidence of rejection. ${ }^{(37)}$ Its use in the initial transplant is related to complications in healing of the surgical wound ${ }^{(38)}$ and the increased incidence of bacterial infections. ${ }^{(33)}$ Other adverse events include proteinuria, dyslipidemia, low platelet count, edema, hypertension, acne, and interstitial pneumonitis. ${ }^{(39)}$

\section{Induction therapy}

This is characterized by a more intensive initial immunosuppression, seeking to reduce the incidence of acute rejection and facilitate the introduction of maintenance immunosuppressors. ${ }^{(1)}$ In the latest ISHLT registry, approximately $50 \%$ of the HT received some form of induction therapy. ${ }^{(2)}$ Despite its use with positive results in reducing the incidence of acute rejection in the initial HT, its routine use is not recommended, since it has not demonstrated an impact on the reduction of mortality. ${ }^{(40)}$ The most used classes of drugs include antilymphocyte antibodies (thymoglobulin) and interleukin-2 antagonists (basiliximab).

\section{LATE COMPLICATIONS}

\section{Cardiac allograft vasculopathy}

Cardiac allograft vasculopathy is among the primary causes of death after the first year of HT, and it is the most important limiting factor in long-term survival, along with neoplasms, with an incidence of $8 \%$ in the first year, $30 \%$ in 5 years, and $50 \%$ in 10 years. ${ }^{(2)}$ This disease, of atherosclerotic nature, is an insidious complication with fast progression, characterized by persistent perivascular inflammation and intimal hyperplasia, and has clinical manifestations similar to those of coronary artery disease, such as arrhythmias, myocardial infarction, HF, and sudden death. It has limited clinical treatment, with retransplant as the only definitive therapeutic option. In the clinical presentation, angina pectoris is rarely present, but despite the discreet symptoms, it has all the classic complications of coronary artery disease.

Pathogenesis is controversial and probably multifactorial; and the following risk factors should be taken into account: donor's age, presence of anti-HLA antibodies, CMV infection, dyslipidemias, systemic arterial hypertension, diabetes mellitus, obesity, and smoking. The loss of an intact and functioning endothelium, combined with chronic immunological attack, may be the triggers that result in migration and proliferation of smooth muscle cells. ${ }^{(41)}$

Early diagnosis of CAV is limited due to scarcity of clinical symptoms of ischemia in the denervated graft; low sensitivity of the coronary cineangiography that frequently underestimates the severity and the extension of the disease; the involvement of small intramyocardial vessels; and occurrence of functional coronary alterations independent of morphological changes. ${ }^{(42)}$ Thus, the diagnosis of CAV is always a clinical challenge. Generally silent due to the denervation of the graft, acute myocardial infarction and sudden death may be its first manifestation, as well as the development and onset of signs and symptoms of $\mathrm{HF}^{(43)}$

Coronary cineangiography is still the standard for CAV diagnosis in most transplant centers, despite its low sensitivity, and the angiographic detection of significant epicardial coronary stenosis implies a poor prognosis. Among the noninvasive diagnostic methods, the stress echocardiography with dobutamine has been used both for diagnosis and to predict cardiovascular events in late follow-up, with a high negative predictive value. ${ }^{(44)}$

Intravascular ultrasound is the most sensitive tool for diagnosis of CAV. It allows a reproducible view not only of the true luminal diameter, but also of the appearance and thickness of the intimal and medium layers. ${ }^{(4)}$ It has already been demonstrated that the progression of maximal intimal thickness $\geq 0.5 \mathrm{~mm}$ in the first year (baseline change to one year) after the transplant, seems to be a reliable marker for subsequent mortality, major non-fatal cardiovascular events, and the development of angiographic CAV up to five years after transplant. ${ }^{(41)}$

Once installed, due to its diffuse obliterative character, treatment of CAV remains very limited and with little impact. Efforts for its prevention, in this way, are necessary and of extreme importance. After the transplant, 
primary prevention should include optimization of immunosuppressive therapy, rigorous control of common cardiovascular risk factors (hypertension, diabetes, obesity, smoking, and sedentary lifestyle), and strategies for the prevention of CMV infection. ${ }^{(1)}$ It is advisable to use statins and diltiazem in the initial transplant as a strategy to reduce the incidence and progression of $\mathrm{CAV}^{(46,47)}$ The mTOR inhibitors (everolimus and sirolimus), due to their potent antiproliferative effect, including of smooth muscle cells, demonstrated in randomized studies a reduction in the incidence and evolution of post-HT CAV and have been recommended when diagnosis is established. . $^{(1,32,33,34)}$ The use of an antiplatelet agent is empirical in diagnosis of CAV.$^{(1)}$ Revascularization strategies (surgical or percutaneous) are limited due to the diffuse pattern of the disease, with distal predominance. Retransplant is the only definitive treatment for CAV, but survival is lower if compared to the first transplant. ${ }^{(48)}$

\section{Neoplasms}

Neoplasms are among the primary causes of late mortality after HT, with a two-to-four-fold increase in risk as compared to the general population. This elevated risk is intimately related to immunosuppression regimen and includes the malignant tumors related to viral infections, such as non-Hodgkin's lymphoma and Hodgkin's lymphoma (as a part of the post-transplant lymphoproliferative disease) - both linked to infection by Epstein-Barr virus, Kaposi sarcoma (related to the human herpes-virus 8), anogenital cancers (linked to the human papilloma virus), and hepatic cancer (hepatitis $\mathrm{B}$ and $\mathrm{C}$ virus). ${ }^{(49)}$

The mTOR inhibitors present with antitumor action, inhibit angiogenesis, block its growth, and delay progression of the cell cycle; in such context they are an option for immunosuppression. ${ }^{(1,50)}$

\section{CARDIAC TRANSPLANT IN CHAGAS' DISEASE}

In the Brazilian scenario, Chagas' cardiomyopathy is the third most common cause for indication of HT. We cannot lose sight of the fact that the Chagas' etiology, in and of itself, is the worst prognosis in patients with cardiomyopathy, if compared to the other etiologies. ${ }^{(51)}$ Moreover, in its advanced and refractory phases to optimized clinical treatment, it is a well-established indication for HT. ${ }^{(52)}$ Nevertheless, the result of the HT in this subgroup of patients is better than that of other etiologies, since the patients are younger, with fewer comorbidities, no reoperations or severe pulmonary hypertension. ${ }^{(53)}$
Due to immunosuppression, there may be a reactivation of the Chagas' disease; however, since it occurs in the acute form of the disease, the response to antiparasitic treatment with benzimidazole or allopurinol is usually favorable.

Reactivation of the infection by Trypanosoma cruzi is described as varying from zero to $50 \%$, but it is rarely the cause of death. Its clinical picture includes cutaneous lesions (chagomas), fever, bone marrow and neurological involvement, as well as signs and symptoms of HF, due to myocarditis. On the other hand, myocarditis can be silent or manifest as severe ventricular dysfunction and cardiogenic shock. Its diagnosis is made by clinical suspicion, by the presence of signs and symptom of infection associated with evidence of the parasite in the blood, in tissues (for example, amastigote nests in an endomyocardial biopsy), or in cerebrospinal fluid.

\section{RESULTS AND LIMITATIONS OF HEART TRANSPLANTATION IN BRAZIL AND IN THE WORLD}

Despite ischemic cardiomyopathy being the most frequent etiology of HF, dilated cardiomyopathy is the primary indication for HT, both in $\operatorname{Brazil}^{(1)}$ and in the world, ${ }^{(2)}$ since it presents with a lower incidence of comorbidities in comparison to ischemic cardiomyopathy. The best results are described in Chagas cardiomyopathy, which stands out as third cause of HT, in Brazil. ${ }^{(54)}$

As to the donor, brain death and its neurohormone and hemodynamic alterations are known to impact the number and outcome of solid organ transplants, but this aspect is even more expressive in HT. ${ }^{(55)}$ Common situations related to brain death, such as the need for high doses of vasopressors and hypernatremia, and prolonged ischemia time in distant organ retrievals (more than 4 hours), make it unfeasible, or provide worse results in an evident manner. In Brazil, in spite of a younger donor profile, with little comorbidity and diagnosis of a great number of brain deaths secondary to trauma, ${ }^{(3)}$ actual donation is limited, especially due to the conditions of these donors. Additionally, for older donors, the lack of availability of echocardiography and coronary cineangiography for evaluation amplifies the problem of making potential donors unviable. In the world, despite a better use of donors, even with an older profile and with more comorbidities, the number of HT is stationary, due to the inherent scarcity. Within this context, the use of circulatory assistance devices to maintain the recipient until the transplant can be performed has been increasing greater. According to the most recent register of ISHLT, ${ }^{(2)}$ almost $40 \%$ of the HT 
performed had some mechanical circulatory assistance device, with the intra-aortic balloon in only $6 \%$ of cases, and $56 \%$ of patients in an outpatient setting. In Brazil, more than half the patients are in a situation of priority for a HT, and the intra-aortic balloon is the circulatory assistance device used in most cases - often for months, due to the high cost of the more advanced devices utilized mostly in Europe and in the United States. Due to severity of patients, besides unavailability of more adequate circulatory assistance devices and the reduced number of effective donors, the mortality rate while in the waiting line in Brazil remains high.

Despite a greater rate of early mortality (first year) in comparison with the data from $\operatorname{ISHLT}^{(2,3)}(81 \%$ versus $68.7 \%$ ), at the end of 10 years, results in Brazil are similar (approximately 50\%), suggesting that the combination of marginal donors and more severe recipients, and with the limited access to more adequate circulatory assistance devices, have a significant impact on early death.

There are many difficulties in performing HT, both in Brazil and in the world, especially involving aspects of donors and recipients. While in developed countries the apex of available donors has been reached and we see an ever increasing use of circulatory assistance devices, in Brazil there is great potential, both in an increase of effective donors, and in the use of circulatory assistance devices, which could impact positively the number and results of HT. For this, it is necessary that the entire healthcare system be involved, with efforts in notification and in care for potential donors, support for the HT centers, including the financing of mechanical circulatory assistance programs.

\section{CONCLUSION}

Heart transplant is the definitive gold standard surgical approach to treat refractory heart failure. However, the scarcity of donors limits the performance of a greater number of heart transplants, a situation that has been increasing the use of mechanical circulatory assistance devices. With well-established indications and contraindications, besides the diagnosis and treatment of rejection by means of defined protocols of immunosuppression, the results of heart transplantation are very favorable. Among the early complications that can impact on survival, we highlight primary graft failure, right ventricle dysfunction, and infections; whereas late complications include CAV and neoplasms. Despite the difficulties in performing heart transplants, especially due to scarcity of donors and the high mortality in the waiting list in Brazil, there is great potential both in the growth of effective donors, and in the use of circulatory assistance devices, which could positively impact the number and results of cardiac transplantation.

\section{REFERENCES}

1. Bacal F, Neto JD, Fiorelli Al, Mejia J, Marcondes-Braga FG, Mangini S, Oliveira Jde L Jr, de Almeida DR, Azeka E, Dinkhuysen JJ, Moreira Mda C, Neto $J M$, Bestetti RB, Fernandes JR, Cruz Fd, Ferreira LP, da Costa HM, Pereira AA, Panajotopoulos N, Benvenuti LA, Moura LZ, Vasconcelos GG, Branco JN, Gelape CL, Uchoa RB, Ayub-Ferreira SM, Camargo LF, Colafranceschi AS, Bordignon S, Cipullo R, Horowitz ES, Branco KC, Jatene M, Veiga SL, Marcelino CA, Teixeira Filho GF, Vila JH, Montera MW; Sociedade Brasileira de Cardiologia. [II Brazilian Guidelines for Cardiac Transplantation]. Arq Bras Cardiol. 2010;94(1 Suppl):e16-76. Portuguese.

2. Lund LH, Edwards LB, Kucheryavaya AY, Dipchand Al, Benden C, Christie JD, Dobbels F, Kirk R, Rahmel A0, Yusen RD, Stehlik J; International Society for Heart and Lung Transplantation. The Registry of the International Society for Heart and Lung Transplantation: thirtieth official adult heart transplant report--2013; focus theme: age. J Heart Lung Transplant. 2013;32(10):951-64.

3. Associação Brasileira de Transplantes de Órgãos. Registro Brasileiro de Transplantes [Internet]. Ano XX, nº4; 2015. Disponível em: http://www. abto.org.br

4. Myers J, Arena R, Dewey F, Bensimhon D, Abella J, Hsu L, et al. A cardiopulmonary exercise testing score for predicting outcomes in patients with heart failure. Am Heart J. 2008;156(6):1177-83.

5. Drakos S, Kfoury A, Gilbert E, Horne B, Long J, Stringham J, et al. Effect of reversible pulmonary hypertension on outcomes after heart transplantation. J Heart Lung Transplant. 2007;26 (4):319-23.

6. Russo MJ, Chen JM, Hong KN, Stewart AS, Ascheim DD, Argenziano M, et al. Survival after heart transplantation is not diminished among recipients with uncomplicated diabetes mellitus: an analysis of the United Network of Organ Sharing database. Circulation. 2006;114(21):2280-7.

7. Loh E, Bergin J, Couper G, Mudge GJ. Role of panel-reactive antibody crossreactivity in predicting survival after orthotopic heart transplantation. J Heart Lung Transplant. 1994;13(2):194-201.

8. Kobashigawa J, Zuckermann A, Macdonald P, Leprince P, Esmailian F, Luu M, Mancini D, Patel J, Razi R, Reichenspurner H7, Russell S8, Segovia J, Smedira N, Stehlik J, Wagner F; Consensus Conference participants. Report from a consensus conference on primary graft dysfunction after cardiac transplantation. J Heart Lung Transplant. 2014;33(4):327-40.

9. Segovia J, Cosío MD, Barceló JM, Bueno MG, Pavía PG, Burgos R, et al. RADIAL: a novel primary graft failure risk score in heart transplantation. J Heart Lung Transplant. 2011;30(6):644-51.

10. Iyer A, Kumarasinghe G, Hicks M, Watson A, Gao L, Doyle A, et al. Primary graft failure after heart transplantation. J Transplant. 2011;2011:175768.

11. Marasco SF, Esmore DS, Negri J, Rowland M, Newcomb A, Rosenfeldt FL, et al. Early institution of mechanical support improves outcomes in primary cardiac allograft failure. J Heart Lung Transplant. 2005;24(12):2037-42.

12. Stobierska-Dzierzek B, Awad H, Michler RE. The evolving management of acute right-sided heart failure in cardiac transplant recipients. J Am Coll Cardiol. 2001;38(4):923-31. Review.

13. Stewart S, Winters GL, Fishbein MC, Tazelaar HD, Kobashigawa J, Abrams $J$, et al. Revision of the 1990 working formulation for the standardization of nomenclature in the diagnosis of heart rejection. J Heart Lung Transplant. 2005;24(11):1710-20.

14. Berry GJ, Burke MM, Andersen C, Bruneval P, Fedrigo M, Fishbein MC, et al. The 2013 International Society for Heart and Lung Transplantation Working Formulation for the standardization of nomenclature in the pathologic diagnosis of antibody-mediated rejection in heart transplantation. J Heart Lung Transplant. 2013;32(12):1147-62 
15. Wu GW, Kobashigawa JA, Fishbein MC, Patel JK, Kittleson MM, Reed EF, et al. Asymptomatic antibody-mediated rejection after heart transplantation predicts poor outcomes. J Heart Lung Transplant. 2009;28(5):417-22.

16. Kfoury AG, Hammond ME, Snow GL, Drakos SG, Stehlik J, Fisher PW, et al. Cardiovascular mortality among heart transplant recipients with asymptomatic antibody-mediated or stable mixed cellular and antibody-mediated rejection. J Heart Lung Transplant. 2009;28(8):781-4.

17. Kfoury AG, Snow GL, Budge D, Alharethi RA, Stehlik J, Everitt MD, et al. A longitudinal study of the course of asymptomatic antibody-mediated rejection in heart transplantation. J Heart Lung Transplant. 2012;31(1):46-51.

18. Costanzo MR, Dipchand A, Starling R, Anderson A, Chan M, Desai S, Fedson S, Fisher P, Gonzales-Stawinski G, Martinelli L, McGiffin D, Smith J, Taylor D, Meiser B, Webber S, Baran D, Carboni M, Dengler T, Feldman D, Frigerio M, Kfoury A, Kim D, Kobashigawa J, Shullo M, Stehlik J, Teuteberg J, Uber P, Zuckermann A, Hunt S, Burch M, Bhat G, Canter C, Chinnock R, Crespo-Leiro M, Delgado R, Dobbels F, Grady K, Kao W, Lamour J, Parry G, Patel J, Pini D, Towbin J, Wolfel G, Delgado D, Eisen H, Goldberg L, Hosenpud J, Johnson M, Keogh A, Lewis C, O'Connell J, Rogers J, Ross H, Russell S, Vanhaecke J; International Society of Heart and Lung Transplantation Guidelines. The International Society of Heart and Lung Transplantation Guidelines for the care of heart transplant recipients. J Heart Lung Transplant. 2010;29(8):914-56.

19. Opelz G, Döhler B, Laux G; Collaborative Transplant Study. Long-term prospective study of steroid withdrawal in kidney and heart transplant recipients. Am J Transplant. 2005;5(4 Pt 1):720-8.

20. Taylor DO, Barr ML, Radovancevic B, Renlund DG, MentzerJr RM, Smart FW, et al. A randomized, multicenter comparison of tacrolimus and cyclosporine immunosuppressive regimens in cardiac transplantation: decreased hyperlipidemia and hypertension with tacrolimus. J Heart Lung Transplant. 1999;18(4):336-45.

21. Reichart $B$, Meiser $B$, Viganò $M$, Rinaldi $M$, Yacoub $M$, Banner NR, et al. European multicenter tacrolimus heart pilot study: three year follow-up. J Heart Lung Transplant. 2001;20(2):249-50.

22. Kobashigawa JA, Miller LW, Russell SD, Ewald GA, Zucker MJ, Goldberg LR, Eisen HJ, Salm K, Tolzman D, Gao J, Fitzsimmons W, First R; Study Investigators. Tacrolimus with mycophenolatemofetil (MMF) or sirolimus vs. cyclosporine with MMF in cardiac transplant patients: 1-year report. Am J Transplant. 2006;6(6):1377-86.

23. Grimm M, Rinaldi M, Yonan NA, Arpesella G, Arizón Del Prado JM, Pulpón LA, et al. Superior prevention of acute rejection by tacrolimus vs. cyclosporine in heart transplant recipients--a large European trial. Am J Transplant. 2006; 6(6):1387-97.

24. Mentz RM Jr, Jahania MS, Lasley RD. Tacrolimus as a rescue immunosuppressant after heart and lung transplantation. The US multicenter FK506 Study group. Transplantation. 1998;65(1):109-13

25. Kobashigawa J, Miller L, Renlund D, Mentzer R, Alderman E, Bourge R, et al. A randomized active-controlled trial of mycophenolatemofetil in heart transplant recipients. Transplantation. 1998;66(4):507-15.

26. Hosenpud JD, Bennett LE. Mycophenolatemofetil versus azathioprine in patients surviving the initial cardiac transplant hospitalization: an analysis of the Joint UNOS/ISHLT Thoracic Registry. Transplantation. 2001;72(10):1662-5.

27. Keogh A. Long-term benefits of mycophenolate mofetil after heart transplantation. Transplantation. 2005;79(3 Suppl):S45-6. Review. Erratum in: Transplantation. 2005;79(8):986

28. O'Neill JO, Edwards LB, Taylor DO. Mycophenolate mofetil and risk of developing malignancy after orthotopic heart transplantation: analysis of the transplant registry of the ISHLT. J Heart Lung Transplant. 2006;25(10):1186-91.

29. Eisen HJ, Kobashigawa JA, Keogh A, Bourge R, Renlund D, Mentzer R. Threeyear results of a randomized, double-blind, controlled trial of mycophenolate mofetil versus azathioprine in cardiac transplant recipients. J Heart Lung Transplant. 2005;24(5):517-25

30. Bacal F, Silva CP, Bocchi EA, Pires PV, Moreira LF, Issa VS, et al. Mycophenolate mofetil increased Chagas' disease reactivation in heart transplanted patients: comparison between two different protocols. Am J Transplant. 2005;5(8):2017-21.
31. Bestetti RB, Souza TR, Lima MF, Theodoropoulos TA, Cordeiro JA, Burdmann EA. Effects of a mycophenolate mofetil-based immunosuppressive regimen in Chagas' heart transplant recipients. Transplantation. 2007;84(3):441-2.

32. Eisen HJ, Tuzcu EM, Dorent R, Kobashigawa J, Mancini D, Valantine-von Kaeppler HA, Starling RC, Sørensen K, Hummel M, Lind JM, Abeywickrama $\mathrm{KH}$, Bernhardt P; RAD B253 Study Group. Everolimus for the prevention of allograft rejection and vasculopathy in cardiac-transplant recipients. N Engl J Med. 2003;3499(9):847-58.

33. Keogh A, Richardson M, Ruygrok P, Spratt B, Galbraith A, O'Driscoll G, et al. Sirolimus in de novo heart transplant recipients reduces acute rejection and prevents coronary artery disease at 2 years: a randomized clinical trial. Circulation. 2004;110(17):2694-700.

34. Mancini D, Pinney S, Burkhoff D, LaManca J, Itescu S, Burke E, et al. Use of rapamycin slows progression of cardiac transplantation vasculopathy. Circulation. 2003;108(1):48-53.

35. Gustafsson F, Ross HJ. Proliferation signal inhibitors in cardiac transplantation. Curr Opin Cardiol. 2007;22(2):111-6. Review.

36. Chapman R, Valantine H, Albanell J, Arns WA, Campistol JM, Eisen H, et al. Proliferation signal inhibitors in transplantation: questions at the cutting edge of everolimus therapy. Transplant Proc. 2007;39(10):2937-50. Review.

37. Zuckerman A, Aliabadi AZ. Calcineurin-inhibitor minimization protocols in heart transplantation. Transpl Int. 2009;22(1):78-89. Review.

38. Zakliczynski M, Nozynski J, Kocher A, Lizak MK, Zakliczynska H, Przybylski $\mathrm{R}$, et al. Surgical wound-healing complications in heart transplant recipients treated with rapamycin. Wound Rep Reg. 2007;15(3):316-21.

39. Rothenburger M, Zuckermann A, Bara C, Hummel M, Strüber M, Hirt S, Lehmkuhl H; Certican Consensus Study Group. Recommendations for the use of everolimus (certican) in heart transplantation: results from the second German-Austrian certican consensus conference. J Heart Lung Transplant. 2007;26(4):305-11.

40. Uber $\mathrm{P}, \mathrm{Mehra} \mathrm{M}$. Induction therapy in heart transplantation: is there a role? J Heart Lung Transpl. 2007;26(3):205-9. Review.

41. Ewel CH, Foegh ML. Chronic graft rejection: accelerated transplant arteriosclerosis. Immunol Rev. 1993;134:21-31. Review.

42. Schmauss D, Weis M. Cardiaca allograft vasculopathy. Recent developments. Circulation. 2008;117(16):2131-41.

43. Calé R, Rebocho MJ, Aguiar C, Almeida M, Queiroz E Melo J, et al. Diagnóstico, prevenção e tratamento da doença vascular do aloenxerto. Rev Port Cardiol. 2012;31(11):721-30. Review.

44. Bacal F, Moreira L, Souza G, Rodrigues AC, Fiorelli A, Stolf N, et al. Dobutamine stress echocardiography predicts cardiac events or death in asymptomatic patients long-term after heart transplantation: 4-year prospective evaluation. J Heart Lung Transplant. 2004;23(11):1238-44.

45. Kobashigawa JA, Tobis JM, Starling RC, Tuzcu EM, Smith AL, Valantine $H A$, et al. Multicenter intravascular ultrasound validation study among heart transplant recipients. J Am Coll Cardiol. 2005;45(9):1532-7.

46. Kobashigawa J, Katznelson S, Laks H, Johnson J, Yeatman L, Wang X, et al. Effect of pravastatin on outcomes after cardiac transplantation. N Engl $\mathrm{J}$ Med. 1995:333(10):621-7.

47. Schroeder J, Gao S, Alderman E, Hunt S, Johnstone I, Boothroyd D, et al. A preliminary study of diltiazem in the prevention of coronary artery disease in heart-transplant recipients. N Engl J Med. 1993;328(3):164-70.

48. Srivastava R, Keck BM, Bennett LE, Hosenpud JD. The results of cardiac retransplantation: an analysis of the Joint International Society for Heart and Lung Transplantation/United Network for Organ Sharing Thoracic Registry. Transplantation. 2000;70(4):606-12.

49. Engels EA, Pfeiffer RM, Fraumeni JF Jr, Kasiske BL, Israni AK, Snyder JJ, et al. Spectrum of cancer risk among US solid organ transplant recipients. JAMA. 2011;306(17):1891-901.

50. Amato R, Jac J, Giessinger S, Saxena S, Willis J. A phase 2 study with a daily regimen of the oral mTOR inhibitor RAD001 (everolimus) in patients with metastatic clear cell renal cell cancer. Cancer. 2009;115(11):2438-46. 
51. Freitas HF, Chizzola PR, Paes AT, Lima AC, Mansur AJ. Risk stratification in a Brazilian hospital-based cohort of 1220 outpatients with heart failure: role of Chagas' heart disease. Int J Cardiol. 2005;102(2):239-47.

52. Andrade JP, Marin-Neto JA, Paola AA, Vilas-Boas F, Oliveira GM, Bacal F, et al. I Diretriz Latino Americana para o Diagnóstico e Tratamento da Cardiopatia Chagásica. Arq Bras Cardiol. 2011:97(2 Supl.3):1-48.

53. Bestetti RB, Theodoropoulos TA. A systematic review of studies on heart transplantation for patients with end-stage Chagas' heart disease. J Card Fail. 2009;15(3):249-55.

54. Bocchi EA, Fiorelli A. The paradox of survival results after heart transplantation for cardiomyopathy caused by Trypanosoma cruzi. First Guidelines Group for
Heart Transplantation of the Brazilian Society of Cardiology. Ann Thorac Surg. 2001;71(6):1833-8.

55. Westphal GA, Caldeira Filho M, Fiorelli A, Vieira KD, Zaclikevis V, Bartz M, Wanzuita R, Teixeira C, Franke C, Machado FO, Friedman G, Andrade J, Matos JD, Lamgaro DM, Silva E, Costa G, Coelho ME, Oliveira MC, Youssef NC, Akamine N, Duarte P, Lisboa R, Mazzali M, Ferraz Neto BH; Task Force of the Brazilian Association of Intensive Medicine, Brazilian Association of Organs Transplantation, Transplantation Center of Santa Catarina. Guidelines for maintenance of adult patients with brain death and potential for multiple organ donations: the Task Force of the Brazilian Association of Intensive Medicine the Brazilian Association of Organs Transplantation, and the Transplantation Center of Santa Catarina. Transplant Proc. 2012;44(8):2260-7. Review. 